\title{
Clinico-Radiographic Examination of Odontogenic Myxoma with Displacement of Unerupted Upper Third Molar: Review of the Literature
}

\author{
Examen Clínico-Radiográfico de un Mixoma Odontogénico con Desplazamiento \\ de un Tercer Molar No Erupcionado: Revisión de la Literatura
}

Hasan Ayberk Altug; Aydin Gulses \& Metin Sencimen

ALTUG, H. A.; GULSES, A. \& SENCIMEN, M. Clinico-radiographic examination of odontogenic myxoma with displacement of unerupted upper third molar: review of the literature. Int. J. Morphol., 29(3):930-933, 2011.

SUMMARY: Odotogenic myxoma is a benign tumor which presents in $3 \%$ to $6 \%$ of all odontogenic tumors. According to the WHO classification, multiple radiolucent areas of varying size, separated by straight or curved bony septa with poorly defined borders are the radiologic characteristics of the condition. We report the case of maxillary odontogenic myxoma in a 21 year old man. The radiological feature of the current case was interesting, due to the size of the lesion and severe displacement of the upper third molar.

KEY WORDS: Odontogenic myxoma; Orthopantomography; Computed tomography; Magnetic resonance imaging; Impacted molar; Cyst.

\section{INTRODUCTION}

Odontogenic myxoma $(\mathrm{OM})$ is classified as a locally invasive, non-metastasizing benign tumor, which presents in $3 \%$ to $6 \%$ of all odontogenic tumors, of the jaws by World Health Organization (WHO). Etiology is unknown. It occurs in the second and third decades, predominantly affects females more than males. It can be said to occur more frequently in mandible than in the maxilla. It frequently displays aggressive infiltration of the adjacent tissue as well as a tendency to recur after surgical removal. Due to the not encapsulated characteristic, complete surgical removal can be difficult. Unfortunately, recurrence average rate of $\mathrm{OM}$ is $25 \%$. There are many differential diagnosis including cysts of jaws, neoplasm, non-odontogenic tumors (Sivakumar et al., 2008; Lo Muzio et al., 1996; Peltola et al., 1994).

Radiographically, the tumor is usually a radiolucent, unilocular or multilocular. Radiographic characteristics can be described as well-defined corticated, well-defined noncorticated, poorly defined, or diffuse. The internal structure of odontogenic myxomas is described as a unilocular or an expansile-multilocular radiolucency. Multilocular lesions are named "tennis racket", "soap bubble" or "honey comb" by some authors (Peltola et al.; MacDonald-Jankowski et al., 2002). Root resorption is rarely seen, though displacement of teeth is relatively common (Peltola et al.; Farman et al., 1993).

The purpose of this case report is to determine clinic and radiographic characteristics of odontogenic myxoma.

\section{CASE REPORT}

A 21-year-old man was referred to our clinic after complaining of painless swelling from the upper right canine tooth to upper right first molar (Figure 1.A). Imaging and histopathologic examinations were performed and odontogenic myxoma was diagnosed.

His orthopantomographic examination revealed a diffuse radiolucent mass in the right buccal sulcus centered on the right maxillary first premolar extending back to the maxillary tuberosity with well-defined appearence (Fig. 1.B). There were no root displacement and resorption. 

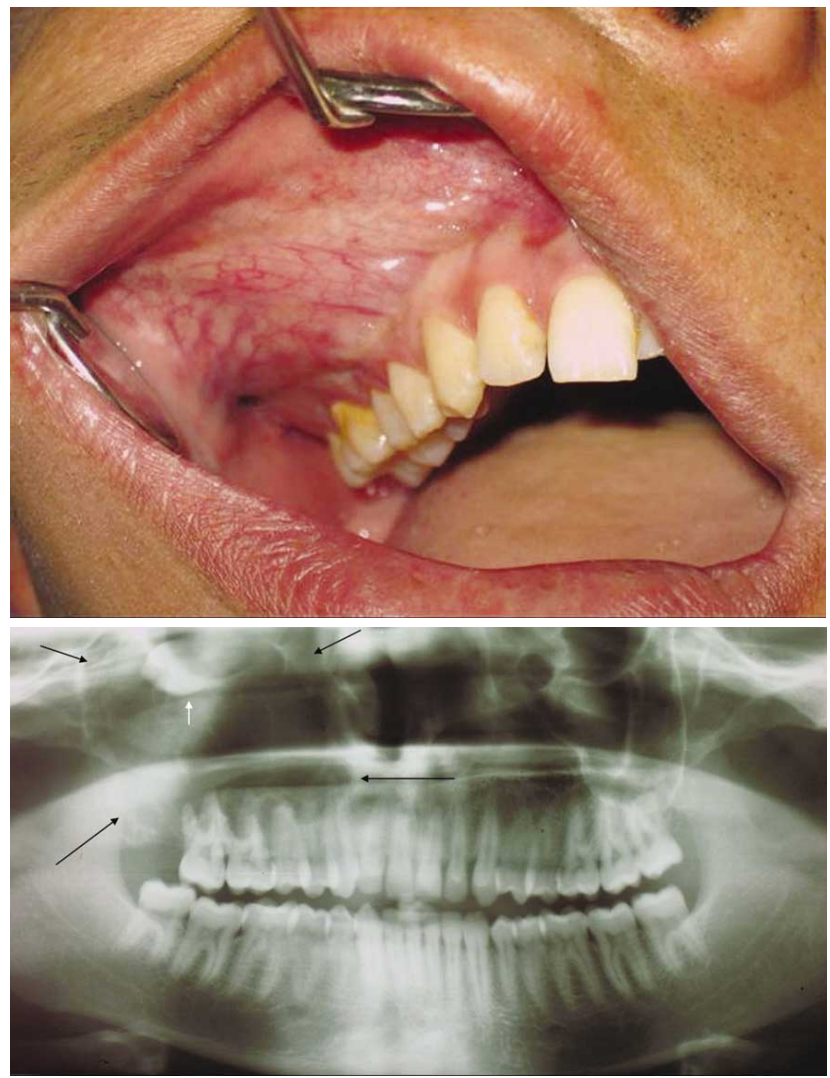

Fig. 1. A. Intraoral view, swelling extending lateral incisor anteriorly to second molar posteriorly B. OPG view Unilocular radiolucent lesion (black arrows) involving in maxilla, including maxillary unerupted third molar displacement to floor of orbita (white arrow shows third molar).

The computed tomography images showed an expansive mass in the right maxilla. There was bone expansion (Fig. 2.A).

Magnetic resonance examination was performed in the case with odontogenic myxoma on a 1.5 tesla unit. Slice thickness was $4 \mathrm{~mm}$ with no interslice gap. MR images of this case showed homogeneous intermediate signal intensity on T1WI (Fig. 2.B), homogeneous high signal intensity on T2WI (Fig. 2.C).

An odontogenic myxoma was suspected on the basis of all these findings. Informed consent was obtained from patient. Incisional biopsy was performed. It revealed an odontogenic myxoma.

Fig. 2. A. Transversal CT image, an expansive mass with unerupted tooth in the right maxilla (white arrow shows third molar) B. Transversal MR Image, homogeneous intermediate signal intensity on T1WI (white arrow shows third molar). C. Transversal MR image, homogeneous high signal intensity on T2WI (white arrow shows third molar).
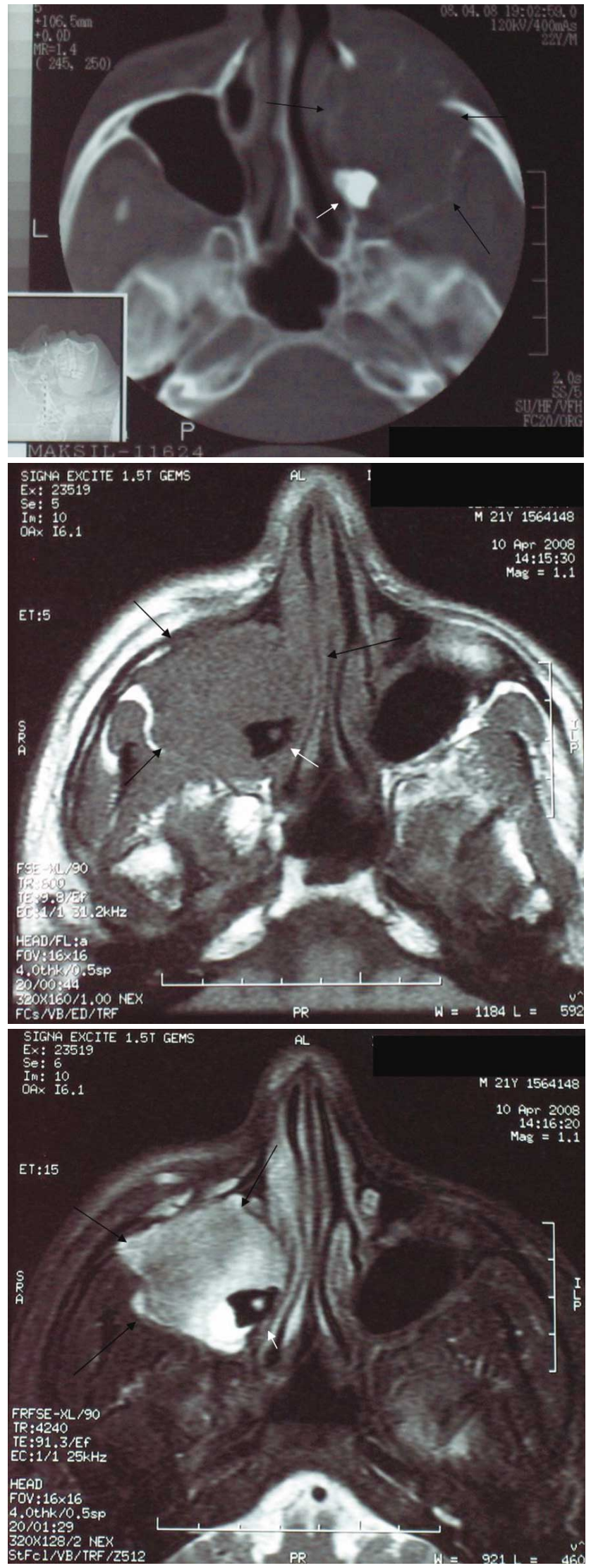
ALTUG, H. A.; GULSES, A. \& SENCIMEN, M. Clinico-radiographic examination of odontogenic myxoma with displacement of unerupted upper third molar: review of the literature. Int. J. Morphol., 29(3):930-933, 2011.

\section{DISCUSSION}

The odontogenic myxoma is a locally invasive benign odontogenic tumor of the jaw. It shows slow and asymptomatic growth (Hernández Vallejo et al., 2001). It derives from the dental papilla, follicle, periodontal ligament (Simon et al., 2004) and usually associates with unerupted, displacement or congenitally missing teeth (Peltola et al.). As stated in literatures (Peltola et al.; Farman et al.), there was no root resorption, whereas there was displacement of upper third molar in this case.

There are conflicting reports in the literature on the radiological features of the odontogenic myxomas. However, the radiological features of the current case are interesting, due to the size of the lesion and the severe displacement of the upper third molar. It may simulate a variety of pathology in the jaws, such as common odontogenic-nonodontogenic cysts (Fig. 3.A), non-odontogenic tumors like central giant cell granuloma (Fig. 3.B) and neoplasm like ameloblastoma (Fig. 4.A) or Langerhans cell histiocytosis (Fig. 4.B) (Sivakumar et al.; Lo Muzio et al.; Peltola et al.; Altug et al., 2010). Table shows the radiographic features of the pathology with the similar radiographic features in our experiences. Odontogenicnonodontogenic cysts which may present as interradicular unilocular radiolucencies in the jaws include radicular cysts, odontogenic keratocysts. They rarely produce divergence of the roots of two adjacent teeth (Farman et al.). Odontogenic cysts such as radicular cysts show homogeneous low-to-
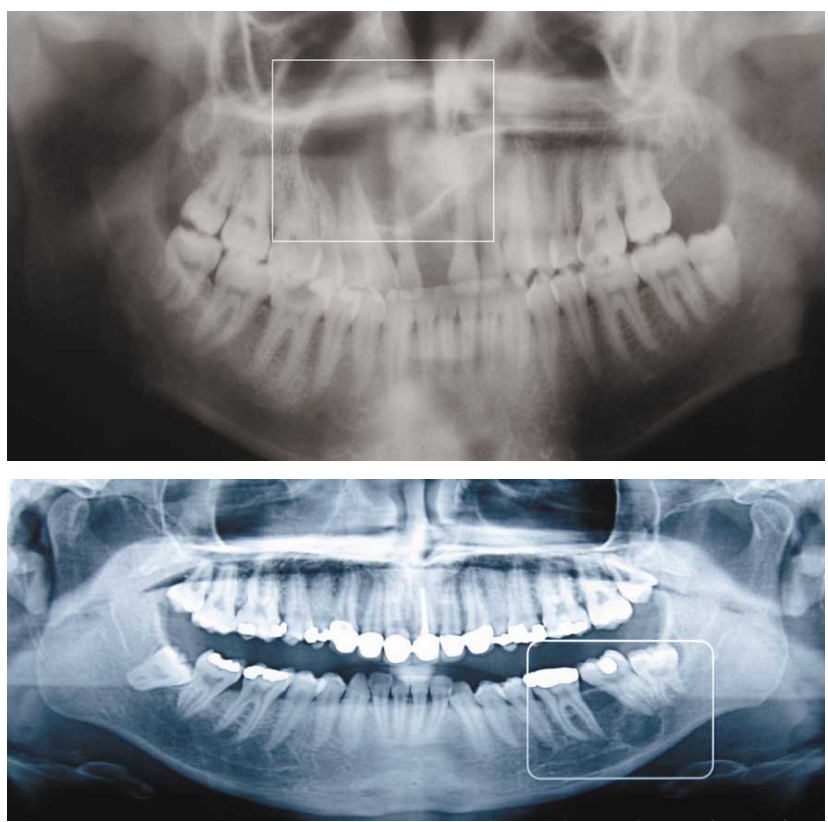

Fig. 3. A. Orthopantomograph of a odontogenic cyst showing a unilocular radiolucency and B. Central giant cell granuloma showing a multilocular radiolucency. intermediate signal intensity on T1WI and homogeneous high signal intensity on T2WI reflecting their cyst fluid (Minami et $a l ., 1996)$. This is almost the same with odontogenic myxoma.

Ameloblastoma is a benign but locally invasive and expansive epithelial odontogenic neoplasm. The mandible is the favored site over the maxilla by about a 4.5:1 ratio. Radiographically, it presents a unilocular or multilocular radiolucent appearance (Williams \& Stewart, 2000). Root resorption and displacement of adjacent tooth are common for ameloblastoma. In the present case, the maxillary lesion was unilocular radiolucency, which caused no root resorption and divergence. These radiographical features are not enough to suggest ameloblastoma. Ameloblastoma usually shows multiple cystic portions of various sizes, which have waterlike signal intensity on T1WI and T2WI (Minami et al.). These findings are useful to differentiate between ameloblastoma and odontogenic myxoma.

Central giant cell granuloma is a non-odontogenic benign tumor, present in a younger population and rarely perforates the cortical bone. Root resorption is rarely seen (Williams \& Stewart).

Within non-odontogenic tumors, Langerhans cell histiocytosis would have a well-circumscribed radiolucent appearance with perforation of the cortical bone. Loss of
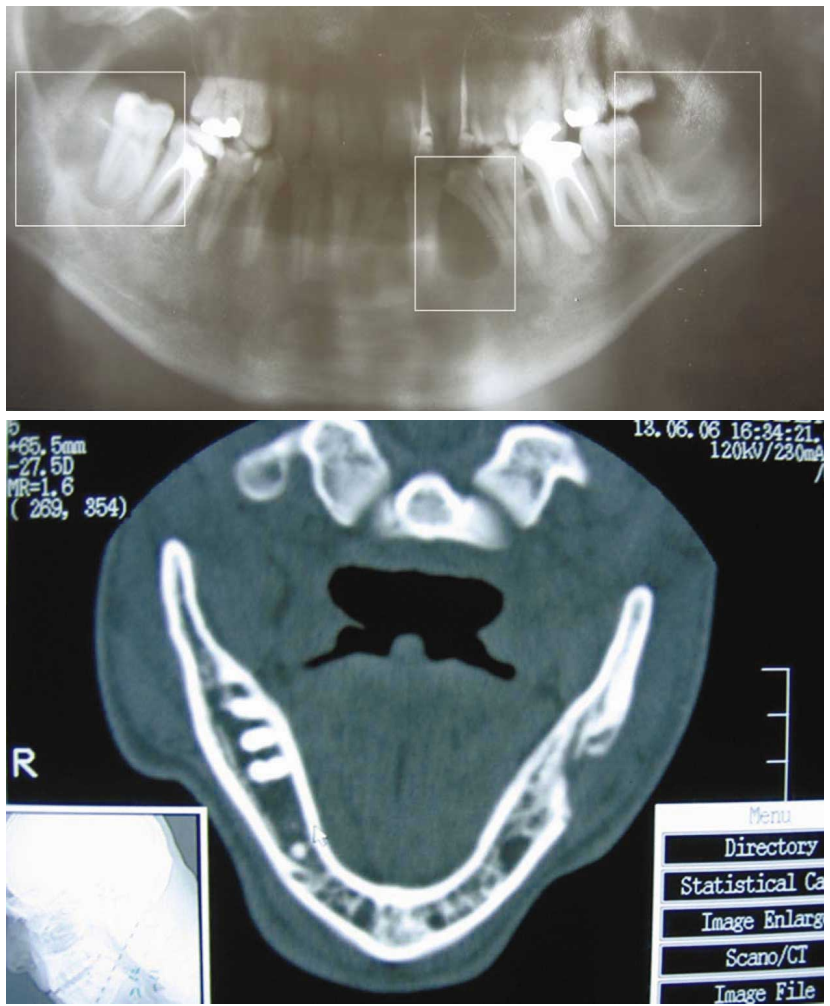

Fig. 4. A. Orthopantomograph of a multiple ameloblastoma and B. Langerhans cell histiocytosis showing an unilocular radiolucency. 
lamina dura and bone resorption may occur surrounding the roots of teeth. Computed tomography shows commonly a unilocular and well-defined mass. Cortical perforation is a differential characteristic for Langerhans cell histiocytosis apart from odontogenic myxoma (Altug et al.; Williams \& Stewart).
In conclusion, clinic and radiographic findings were presented and discussed in the light of recent literature. This case underlines the difficulty in establishing a correct diagnosis, which requires interaction between radiologist, surgeon and pathologist. The radiographic appearance also should be integrated with the clinical history and physical findings.

ALTUG, H. A.; GULSES, A. \& SENCIMEN, M. Examen clínico-radiográfico de un mixoma odontogénico con desplazamiento de un tercer molar no erupcionado: revisión de la literatura.Int. J. Morphol., 29(3):930-933, 2011.

RESUMEN: El mixoma odontogénico es un tumor benigno que se presenta en el 3\% a 6\% de todos los tumores odontogénicos. De acuerdo a la clasificación de la OMS, las características radiológicas de esta patología presentan múltiples áreas radiolúcidas de tamaño variable, separadas por tabiques óseos rectos o curvos, con márgenes mal definidos. Presentamos un caso de mixoma odontogénico maxilar en un hombre de 21 años. La característica radiológica es interesante, debido al tamaño de la lesión y al desplazamiento severo del tercer molar superior.

PALABRAS CLAVE: Mixoma odontogénico; Ortopantomografía; Tomografía computarizada; Resonancia magnética; Molar; Quistes.

\section{REFERENCES}

Altug, H. A.; Alomeroglu, M.; Sahin, S.; Sencimen, M.; Dogan, N. \& Krishnan, D. G. Incidental discovery of asymptomatic radiolucent lesion of the posterior mandible. J. Oral Maxillofac. Surg., 68(4):845-8, 2010.

Farman, A. G.; Nortje, C. J. \& Wood, R. E. Oral and maxillofacial diagnostic imaging. Saint Luis, Mosby, 1993. pp.257-60.

Hernández Vallejo, G.; Cohn, C.; García Peñín, A.; Martínez Lara, S.; Llanes Menéndez, F. \& Montalvo Moreno, J. J. Myxoma of the jaws. Report of three cases. Med. Oral, $6(2): 106-13,2001$.

Lo Muzio, L.; Nocini, P.; Favia, G.; Procaccini, M. \& Mignogna, M. D. Odontogenic myxoma of the jaws: a clinical, radiologic, immunohistochemical, and ultrastructural study. Oral Surg. Oral Med. Oral Pathol. Oral Radiol. Endod., 82(4):426-33, 1996.

MacDonald-Jankowski, D. S.; Yeung, R.; Lee, K. M. \& Li, T. K. Odontogenic myxomas in the Hong Kong Chinese: clinico-radiological presentation and systematic review. Dentomaxillofac. Radiol., 31(2):71-83, 2002.

Minami, M.; Kaneda, T.; Ozawa, K.; Yamamoto, H.; Itai, Y.; Ozawa, M.; Yoshikawa, K. \& Sasaki, Y. Cystic lesions of the maxillomandibular region: MR imaging distinction of odontogenic keratocysts and ameloblastomas from other cysts. AJR Am. J. Roentgenol., 166(4):943-9, 1996.
Peltola, J.; Magnusson, B.; Happonen, R. P. \& Borrman, H. Odontogenic myxoma--a radiographic study of 21 tumours. Br. J. Oral Maxillofac. Surg., 32(5):298-302, 1994.

Simon, E. N.; Merkx, M. A.; Vuhahula, E.; Ngassapa, D. \& Stoelinga, P. J. Odontogenic myxoma: a clinicopathological study of 33 cases. Int. J. Oral Maxillofac. Surg., 33(4):333-7, 2004.

Sivakumar, G.; Kavitha, B.; Saraswathi, T. R. \& Sivapathasundharam, B. Odontogenic myxoma of maxilla. Indian J. Dent. Res., 19(1):62-5, 2008.

Williams, T. P. \& Stewart, J. C. B. Surgical pathology. In: Fonseca, R. J. (Ed.). Oral and Maxillofacial Surgery. Philadelphia, W. B. Saunders Company, 2000. pp.297445.

\section{Correspondence to:}

Hasan Ayberk Altug, DDS, PhD

Gulhane Military Medical Academy

Dep. of Oral\&Maxillofacial Surgery

Ankara

TURKEY

Tel:903123046079

Email: aybork@yahoo.com

Received: 20-12-2010

Accepted: 25-04-2011 